\title{
Leadership Styles of Hospital Nurses: Impacts on the Work Process and Organizational Climate
}

\author{
Ferreira Barbosa DB, da Silva Guedes LC, Abi Rached CD,* Alves Teixeira CA, dos Santos LV, de Souza Almeida T
}

University of São Paulo (USP) / School of Nursing / Sao Paulo, SP, Brazil

\begin{abstract}
Introduction: The kinds of leadership have been discussed not only in academia but in the corporate world. It has been observed that some types have negatively influenced the organizational environment and the work process.
\end{abstract}

Objective: To analyze the leadership practiced by nursing professionals within the hospital environment and their impacts on the work process and organizational climate.

Methods: This is a scoping review whose objective was to map the main concepts about leadership styles and influence, examining and summarizing the existing research gaps. The following databases were used: MEDLINE, LILACS, IBESCS, PUBMED, and ENDENF.

Results: Twenty nine articles were selected. The autocratic leadership style was the most cited as unfavorable for maintaining a favorable organizational climate for workers' welfare.

Conclusion: It is believed that the leadership practiced by the nurse influences positively or negatively on the corporate environment and well-being at work.

Keywords: Leadership, Nurses, Hospitals

\section{Background}

Leadership is increasingly becoming an essential and indispensable tool for nursing, due to actions and practices of nurses should always be related to an adequate articulation and goal achievement persuit. ${ }^{1}$ Leadership is an essential competence to nursing teamwork engagement, as it leads the actions in the persuit of effective results. The managerial model of the nurse should be related to a good articulation within the team, with the presence of effective, clear, and objective communication, dialogue among members, and the presence of a risk-taking and responsibility posture. ${ }^{1-3}$
The nurse has a generalist, humanistic, critical, and reflective education, and in this sense, during their training, they seek to develop leadership according to these pillars of competence: Knowledge, Skills, and Behaviors. Emphasizing the formation of professional values such as commitment, responsibility, empathy, decision-making and communication skills. ${ }^{1,3}$ When exercised in a positive way, leadership raises care quality provided to user, assisting in patient's safety, strengthens teamwork, reduces absenteeism, increases life quality at work, among other aspects. ${ }^{2}$

Leadership is considered a competence that should be developed by professionals in management positions, regardless of

\begin{tabular}{|l|l|}
\hline \hline Quick Response Code: & *Corresponding author: Chennyfer D A Rached, Dr Enéas Carvalho de Aguiar Avenue, 419 - \\
Cerqueira Cesar, Sao Paulo - SP, Zip Code: 05403-000, Brazil \\
Received: 01 December, 2021 \\
Citation: Ferreira Barbosa DB, da Silva Guedes LC, Abi Rached CD, Alves Teixeira CA, dos San- \\
tos LV, et al. Leadership Styles of Hospital Nurses: Impacts on the Work Process and Organiza- \\
tional Climate. Trends Nur Health Care Res. 2021;1(3):1-8. DOI: \\
10.53902/TNHCR.2021.01.000511
\end{tabular}


whether they are in the healthcare field. For there to be adequate organizational performance, effectiveness in work processes, quality management, as well as maintaining a positive and transforming organizational climate, subordinates need to believe in the organization's purposes and be in synergy with the leaders..$^{3-5}$ But how to do this? How does the leader know the subordinates, their thoughts, and direct the most appropriate leadership style?

There are several theories about leadership styles, all of which seek to answer the leader's relationship with his or her subordinates, emphasizing the way the leader orient his or her conduct, which organizational aspects and personality characteristics reflect on the leader's leadership style.

The first leadership scholars believed that a leader was born a leader by his own personality traits; later, other theories emerged strengthening the perception that leadership style can be developed, and that the leader can drive his style according to his work process, organizational climate and culture as well as the team's profile. ${ }^{3}$ Given this context, this scope review has this as guiding question: What are the leadership styles practiced by nurses with a position of leadership within the hospital environment, and their impacts on the work process and organizational climate? Positioned leadership is understood as the position held as a supervisor, coordinator, chief, director, manager, among other similar positions.

It is believed that leadership serves to build an engaged, motivated team, as well as to favor a positive organizational climate and work processes since work in hospitals is complex, stressful, and exhausting. Professionals are sometimes placed in embarrassing and challenging situations which requires nursing team managers to lead in favor of the environment/team synergy.

\section{Objective}

To analyze the leadership styles practiced by nursing professionals within the hospital environment and their impacts on the work process and organizational climate.

\section{Methods}

This study is a scoping review, under Joanna Briggs Institute (JBI) method, which aims to group and synthesize the topic-related knowledge and have a perception of the degree of complexity around it till study present moment. ${ }^{6}$ As to this purpose, the following steps were replicated:

a) Research question definition: Based on the Population, Concept and Context (PCC) strategy for a scoping review, the following were defined: $\mathrm{P}$ - nurse leader (considered leadership as the position held - chiefs, coordinators, supervisors, directors); C - leadership style and C - work processes and organizational climate.

b) Evidence research: The following databases were employed: MedLine, BDENF, LILACS and IBESC through VHL Portal; PUBMED Portal was also employed. The search strategy adopted was 'leadership' and 'nursing team' or 'nursing professional' or 'nurses and nurses' or 'hospital nursing service', as shown in Table 1. The third step was the studies selection, which was done independently by two researchers using the Zotero software. A third researcher decided on the conflicts in the absence of consensus. The inclusion criteria considered were: in English and Portuguese, dated from 2016 to 2021, period choice due to the intent of understanding the leadership styles at the present time with a focus on the leadership performed by nurses at hospital environment. Studies that addressed only leadership styles without presenting the impacts were excluded, as well as those that were not in the context of the hospital environment. Excluding theses, essays and works with commentary study designs; articles that examined leadership styles but did not refer to nurses; that described the effects on the leader and not on the operational processes and work environment; and articles that analyzed the effects on the worker's health specifically, such as Burnout Syndrome.

Table 1: Search strategies in the databases selected for the study. Brazil, 2021.

\begin{tabular}{|l|l|}
\hline Base & Descriptors \\
\hline Medline & 'leadership' and 'nursing team' or 'nursing professional' or 'nurses and nurses' or 'hospital nursing service' \\
\hline BDEnf & 'leadership' and 'nursing team' or 'nursing professional' or 'nurses and nurses' or 'hospital nursing service' \\
\hline Lilacs & 'leadership' and 'nursing team' or 'nursing professional' or 'nurses and nurses' or 'hospital nursing service' \\
\hline IBESC & 'leadership' and 'nursing team' or 'nursing professional' or 'nurses and nurses' or 'hospital nursing service' \\
\hline PubMed & (leadership) and (nursing team or nursing professional or nurses or nurses) and (hospital nursing service) \\
\hline
\end{tabular}

c) Data extraction: The Preferred Reporting Items for Systematic Reviews and Meta-Analyses Extension for Scoping Reviews (PRISMA-ScR) Checklist was used to systematize the data.
PRISMA-ScR consists of 22 items categorized into: Title, Abstract, Introduction, Method, Results, Discussion, and Conclusion, forms were created in the Excel program for independent 
completion by the two researchers. Information was collected such as: studies characteristics, population characteristics, and leadership styles.

d) Results summarization: Data was grouped by categories: year, authors, leadership style and main findings. According to the data analysis, a structure was developed with its configuration based on studies characteristics and the leadership styles.

e) Presentation of the results obtained.

\section{Results}

A total of 501 articles were found; according to exclusion criteria, 397 were excluded by reading the titles, 51 were excluded after reading the abstract, and 24 after reading the full text, and 29 articles that answered the research question remained Figure 1.

The description of the articles that answer the research question is presented in the Table 2 below.

The summary of study design is in the Table 3.
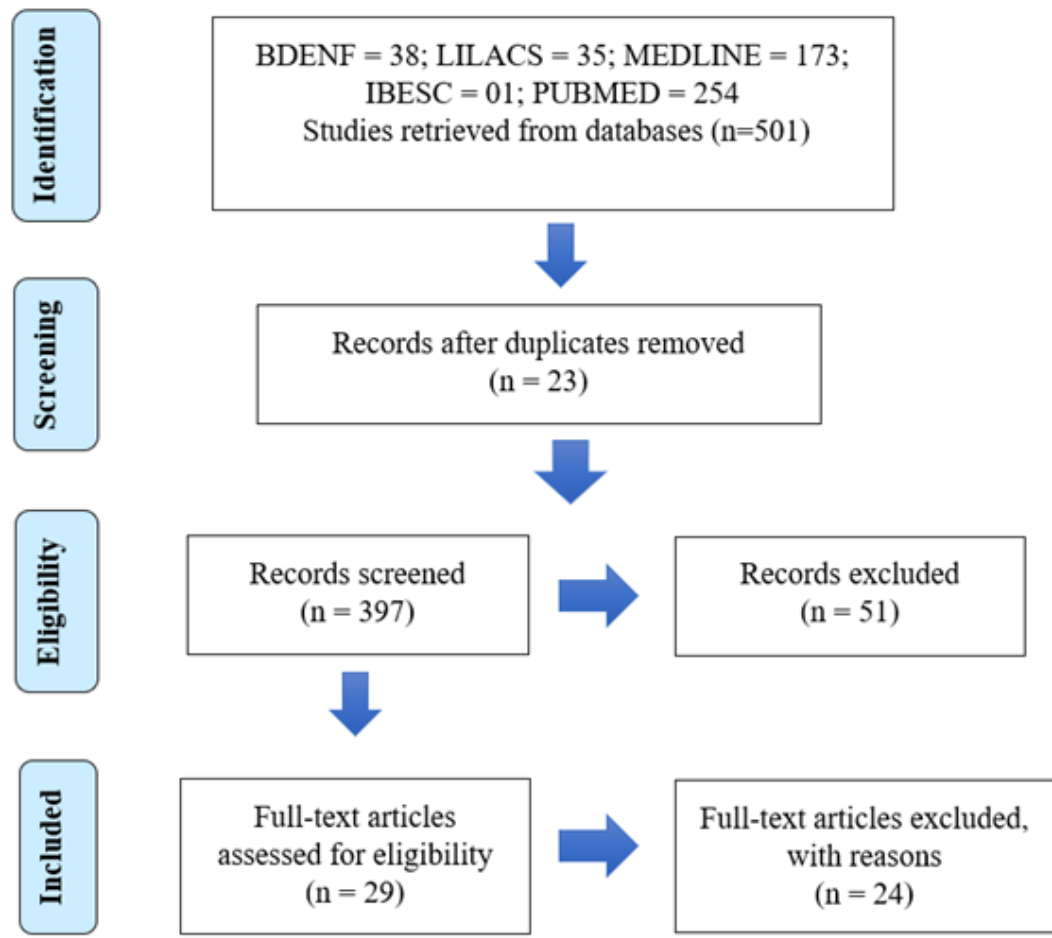

Figure 1: The PRISMA flow diagram for identification and selection of primary studies included in the systematic review. Brazil, 2021.

Table 2: Summary of the main findings of the articles and thematic categories. Brazil, 2021.

\begin{tabular}{|c|c|c|c|}
\hline Year & Authors & Leadership Style & Main findings \\
\hline 2016 & Andrigue, et al. & Situacional styles & $\begin{array}{l}\text { The nurse leader can adopt different behaviors and actions in order to make } \\
\text { the group responsible for and involved in care process in an articulated and } \\
\text { collective way, establishing open communication channels and developing } \\
\text { participatory leadership processes, sensitive to the team needs. The results } \\
\text { can have a positive or negative impact on the work processes once this type } \\
\text { of leadership needs a mature and cohesive team. }\end{array}$ \\
\hline 2016 & $\begin{array}{l}\text { Malik N, Dhar RL, } \\
\text { Handa SC. }\end{array}$ & Authentic leadership & $\begin{array}{l}\text { Authentic leadership is positively linked to employee creativity since sharing } \\
\text { information is a part of it. }\end{array}$ \\
\hline 2016 & Yeh, et al, 2016 & Initiating leadership style & $\begin{array}{l}\text { Personality traits such as Conscientiousness, Extraversion, Agreeableness, } \\
\text { Openness Neuroticism influence Leadership Style. Top nurses with high } \\
\text { openness would improve their efficiency if they worked under a high initiat- } \\
\text { ing structure and a low considering leadership style. }\end{array}$ \\
\hline 2016 & $\begin{array}{l}\text { Morsiani G, Bagnas- } \\
\text { co A, Sasso L }\end{array}$ & $\begin{array}{l}\text { Transformational Leadership, } \\
\text { passive-avoidant styles and } \\
\text { Laissez-faire style }\end{array}$ & $\begin{array}{l}\text { Describes transformational leadership as a path for process improvement } \\
\text { and worker satisfaction. Laissez-faire style brings negative points regarding } \\
\text { satisfaction and climate since the workers do not have engagement and har- } \\
\text { mony with the team's common objectives. }\end{array}$ \\
\hline 2016 & Choi, SL et al. & Transformational Leadership & Transformational Leadership results unfold engagement and job satisfaction \\
\hline 2016 & $\begin{array}{l}\text { Abdelhafiz, Allouba- } \\
\text { ni and Almatari }\end{array}$ & $\begin{array}{l}\text { Transformational and transac- } \\
\text { tional leadership styles }\end{array}$ & $\begin{array}{l}\text { The transformational leadership behaviors increase nurses job satisfaction } \\
\text { contributing to an increased retention of employees }\end{array}$ \\
\hline
\end{tabular}




\begin{tabular}{|c|c|c|c|}
\hline 2016 & $\begin{array}{l}\text { Alshahrani FMM, } \\
\text { Baig LA }\end{array}$ & Transformational Leadership & $\begin{array}{l}\text { Describes the transformational leadership positive factors on climate as well } \\
\text { as worker satisfaction, improving work processes. }\end{array}$ \\
\hline 2016 & Brewer, CS, et al & Transformational Leadership & $\begin{array}{l}\text { The author associates Transformational Leadership with greater commit- } \\
\text { ment from the worker in the development of his activities and job satisfac- } \\
\text { tion. }\end{array}$ \\
\hline 2016 & $\begin{array}{l}\text { Fallata, F, Laschin- } \\
\text { ger, HK }\end{array}$ & Authentic leadership & $\begin{array}{l}\text { The Authentic leadership creates supportive environments for professional } \\
\text { action and is more likely to improve job satisfaction. }\end{array}$ \\
\hline 2016 & Jackson, C. & Authentic leadership & $\begin{array}{l}\text { The situational leader has the knowledge and skills to nurture the subor- } \\
\text { dinate's professional development, assisting in development of self-aware- } \\
\text { ness, improving team engagement and patient care practices. }\end{array}$ \\
\hline 2016 & $\begin{array}{l}\text { Spence, L and Read, } \\
\text { EA }\end{array}$ & Authentic leadership & $\begin{array}{l}\text { This author addresses how this leadership style influences the emotional as- } \\
\text { pects of the worker, highlighting that it reduces emotional stress. }\end{array}$ \\
\hline 2016 & Asiri, SA, et al. & Transformational leadership & $\begin{array}{l}\text { This leadership style can play a key role in promoting organizational com- } \\
\text { mitment among nurses working at hospitals, improving nursing care pro- } \\
\text { cesses. }\end{array}$ \\
\hline 2017 & Silva, VLS, et al. & Transformational Leadership & $\begin{array}{l}\text { It creates a trusting and power-sharing environment, valuing those who are } \\
\text { led, generating a work environment that is favorable to worker's well-being } \\
\text { and life quality. }\end{array}$ \\
\hline 2017 & Moura, AA, et al. & $\begin{array}{l}\text { Transformational Leadership, } \\
\text { Authentic leadership, Situacion- } \\
\text { al Leadership, Relacional Lead- } \\
\text { ership Style }\end{array}$ & $\begin{array}{l}\text { A literature review describing that empowerment mediates the effect of } \\
\text { transformational, authentic, situational and relational leadership having a } \\
\text { positive impact on team job satisfaction. }\end{array}$ \\
\hline 2017 & Kaiser, JA. & Transformational leadership & $\begin{array}{l}\text { The leader behaviors impact the level of incivility between staff nurses and } \\
\text { work process. }\end{array}$ \\
\hline 2018 & $\begin{array}{l}\text { Özkan, TF, Yaşar, Ö, } \\
\text { Sevimligül, G. }\end{array}$ & Collaborating style & $\begin{array}{l}\text { The collaborating style leadership favors to maintain a positive climate, re- } \\
\text { ducing conflicts more effectively }\end{array}$ \\
\hline 2018 & Naseem, S; et al. & Transformational styles & $\begin{array}{l}\text { The transformational styles promote positive aspects: professional work en- } \\
\text { vironment, professional relationship, role enactment, autonomy and a job } \\
\text { satisfaction }\end{array}$ \\
\hline 2018 & Saleh, U, et al. & Relational leadership style & $\begin{array}{l}\text { Impact on job satisfaction, turnover, and the quality of patient care they de- } \\
\text { liver. }\end{array}$ \\
\hline 2018 & $\begin{array}{l}\text { García-Sierra, R and } \\
\text { Fernández-Castro, J }\end{array}$ & Transformational leadership & $\begin{array}{l}\text { The transformational leadership positively influences the structural empow- } \\
\text { erment of nurses and work process. }\end{array}$ \\
\hline 2018 & Musinguzi C, et al. & $\begin{array}{l}\text { Transformational leadership, } \\
\text { transactional leadership, Lais- } \\
\text { sez-faire style }\end{array}$ & $\begin{array}{l}\text { Transformational styles had a positive impact on boosting motivation, en- } \\
\text { suring job satisfaction, and consolidating teamwork among healthcare pro- } \\
\text { fessionals, compared to those who demonstrated transactional skills or lais- } \\
\text { sez-faire styles. }\end{array}$ \\
\hline 2019 & Scofano, BSS, et al. & $\begin{array}{l}\text { Transformational Leadership, } \\
\text { Relational leadership style Lais- } \\
\text { sez-faire style/ Passive-avoid- } \\
\text { ant styles }\end{array}$ & $\begin{array}{l}\text { In the Transformational Leadership and Relational leadership style there } \\
\text { is an empowerment of those involved, of communication, and of engage- } \\
\text { ment, which results in greater satisfaction from worker and patient, and } \\
\text { lower rates of medication errors, hospital infections and mortality. The Lais- } \\
\text { sez-faire style and Passive-avoidant styles present some vulnerability points, } \\
\text { such as targeting only task fulfillment and not quality; lack of opportunity } \\
\text { for workers to express new ideas, generating low productivity and low sat- } \\
\text { isfaction. }\end{array}$ \\
\hline 2019 & Pishgooie, AH, et al. & $\begin{array}{l}\text { Transformational and transac- } \\
\text { tional leadership styles }\end{array}$ & $\begin{array}{l}\text { The transformational and transactional leadership styles can reduce nurse's } \\
\text { job stress and intention to leave, so nurse leaders can use combination of } \\
\text { transformational and transactional leadership for improving job satisfaction } \\
\text { and quality of nursing services. }\end{array}$ \\
\hline 2019 & Alloubani A, et al. & Transformational Leadership & $\begin{array}{l}\text { This leadership style has a positive correlation with quality of nursing care, } \\
\text { extra effort, job satisfaction and leader effectiveness. }\end{array}$ \\
\hline 2019 & Moura, AA, et al. & Charismatic leadership & $\begin{array}{l}\text { The Charismatic leadership is considered an important skill for nursing pro- } \\
\text { fessionals as they generate a positive influence in the organizational envi- } \\
\text { ronment. }\end{array}$ \\
\hline \multirow{2}{*}{2020} & \multirow{2}{*}{ Suliman, et al. } & \multirow{2}{*}{$\begin{array}{l}\text { Transformational and transac- } \\
\text { tional leadership styles }\end{array}$} & $\begin{array}{l}\text { The transformational leadership style favors nurses' job satisfaction and re- } \\
\text { duce turnover. }\end{array}$ \\
\hline & & & $\begin{array}{l}\text { The transactional leadership style contributes to a demotivation, negative } \\
\text { organizational climate, followed by a slight intention to leave their jobs. }\end{array}$ \\
\hline
\end{tabular}




\begin{tabular}{|l|l|l|l|}
\hline 2020 & Sabbah IM, et al. & $\begin{array}{l}\text { Transformational leadership } \\
\text { style, Transactional leadership, } \\
\text { Laissez-faire style }\end{array}$ & $\begin{array}{l}\text { Transformational leadership style has a positive effect on worker well-being } \\
\text { and climate while Transactional leadership, Laissez-faire style brings a neg- } \\
\text { ative effect of nursing staff well-being. }\end{array}$ \\
\hline 2020 & Poels, J, et al. & $\begin{array}{l}\text { Transformational and transac- } \\
\text { tional leadership styles, Pas- } \\
\text { sive-avoidant leadership styles }\end{array}$ & \\
\hline 2020 & $\begin{array}{l}\text { Magbity JB; Ofei, } \\
\text { AMA; Wilson, D }\end{array}$ & $\begin{array}{l}\text { Transformational leadership } \\
\text { styles, autocratic and lais- } \\
\text { sez-faire leadership styles }\end{array}$ & $\begin{array}{l}\text { The participative and transformational leadership styles decrease turnover } \\
\text { intention while autocratic and laissez-faire leadership styles increase, which } \\
\text { can be inferred from the relations of organizational climate and worker sat- } \\
\text { isfaction }\end{array}$ \\
\hline Specchia ML, et al. & $\begin{array}{l}\text { Transformational, transaction- } \\
\text { al, Passive-avoidant and lais- } \\
\text { sez-faire styles and authentic } \\
\text { leadership styles }\end{array}$ & $\begin{array}{c}\text { Transformational, Transactional, Passive-avoidant and laissez-faire styles } \\
\text { have a negative correlation with job satisfaction. }\end{array}$ \\
\hline
\end{tabular}

Table 3: Summary of study design.

\begin{tabular}{|l|l|c|c|}
\hline & & Total & \% do total \\
\hline \multirow{3}{*}{ Temporal design } & Cross-sectional & 9 & $31 \%$ \\
Type of data & Longitudinal & 1 & $3 \%$ \\
& Quantitative & 6 & $20 \%$ \\
& Qualitative & 9 & $31 \%$ \\
& Mixed methods & 1 & $3 \%$ \\
& Integrative Review & 3 & $10 \%$ \\
\hline
\end{tabular}

\section{Discussion}

The studies analyzed in this review point out that all leadership styles impact on work processes and organizational climate, with transformational leadership being one of the most favorable styles for obtaining high levels of satisfaction in nursing works, increasing productivity, and achieving a friendly organizational climate. Transformational leaders, through their motivational and inspirational behavior, positively influence the psychological states of employees.

Transformational and transactional leadership styles aid in creating a positive or negative work environment and work-life balance, anticipating problems and trying to solve them through interacting with employees favor a positive effect on employees in the organizational climate, as well as in absenteeism rates, and increase satisfy employees. ${ }^{7-12}$

The Transformative leadership styles makes employees feel part of a cohesive team, with a spirit of commitment and sharing common goals. Transformational leaders seek team development through continuous education and improvement. This leadership style promotes job satisfaction among nurses, which improves performance, a favorable climate and has the most significant impact on healthcare system performance metrics. This kind of leader treat subordinates like people, listening to their concerns and answering questions. ${ }^{7-11,13,14}$
The transformational leader sows a positive result in work accomplishment levels, and leader empowerment, favoring an effective impact on the results of work processes and patient care. This leadership style has a positive correlation with nursing care quality, extra effort, job satisfaction and leader effectiveness. ${ }^{7,9,11,13,15-17}$

Os estilos transformacionais tiveram um impacto positivo no estímulo à motivação, garantindo a satisfação no trabalho e consolidando o trabalho em equipe entre os profissionais de saúde, em comparação com aqueles que demonstraram habilidades transacionais ou estilos laissez-faire. ${ }^{7,10,11,12,14,18}$

The Relational leadership style points towards relationship is one of the fundamental requirements for cooperation among teams. This leadership style prioritizes people management and relationship quality, highlighting that the leader makes his leadership based on support, cooperation, understanding and has problem-solving skills in a way that creates a friendly and trusting work environment, providing safe, quality care to patients, producing better results in relation to nursing processes. ${ }^{3,19}$

The Relational leadership style has similar results to Transformational Leadership, since it promotes teamwork, providing a trusting climate and a horizontal perspective. In both Transformational Leadership and in the Relational leadership style, the team should participate in decisions by giving suggestions, but they should always be thought of and approved by the leader himself. ${ }^{3}$ 
Just as the Relational leadership style, the Charismatic leadership helps maintaining a healthy, stress-free work environment; achieves motivational results through mechanisms such as changing the leader's perceptions about the nature of the work; provides a positive vision of the future; promotes the development of a deep collective identity among the team, increasing individual and collective self-efficacy. ${ }^{20}$

Authentic leadership reveals that leaders who prioritize transparency, self-awareness and seek to promote work ethics are able to empathize with their subordinates, recognizing and understanding their concerns, needs and desires. Thus, this leadership style favors the trust of both leader and subordinates, which brings as a result a more effective performance in work processes as well as worker well-being. ${ }^{14,21-23}$

A positive point to be highlighted in Authentic leadership is that it favors the involvement of the team during decision-making. The fact that the worker can express his personal point of view increases the sense of teamwork and empathy, which consequently promotes the use of a two-way communication process, strengthening mutual trust between leaders and subordinates..$^{14,21,22}$

The studies on Authentic leadership describe that the professional practice and empowerment this type of leadership predisposes increase the degree of job satisfaction. Another item argued is trust development, which makes the work environment healthier, similar to the transformational and relational theories.

The Laissez-faire and passive-avoidant styles bring less favorable results regarding the climate and professional satisfaction of the team. Nurses are pressured to achieve set goals in both of these styles without receiving guidance and practical or emotional support. These leadership styles do not provide clear directions, and therefore employees have to set their own goals, targets, and decision-making processes. ${ }^{11,12,14}$

Staff may feel insecure or unattended because they do not have consistent attention. Just as the laissez-faire and passive-avoidant styles are associated with a negative impact on employee performance measures, they only adopt the autocratic leadership approach. Too much direction or too little communication from a manager may negatively impact staff, leaving them feeling unmotivated and neglected. ${ }^{9,11,14,24}$

Nurse leadership styles can positively or negatively influence the work environment and worker satisfaction. The transformational style provides a positive workplace climate that enhances cooperation and collaboration among staff, thereby providing peer and social support, different from the autocratic and Laiz leadership style that deconstructs the climate of collaboration by increasing staff turnover. ${ }^{14,25}$
Situational Leadership is directly related to team members maturity, their willingness to take responsibility for directing their own behavior. In this sense, if the team is not mature, it may compromise the results of the work process and the work environment itself, since the workers may not feel safe and may not perceive the actions of this type of leader in a positive way. To apply this leadership style, first it is necessary to know the team, and draw strategies that allow it to reach high levels of maturity, thus providing conditions for the team to develop its activities with autonomy and trust among all employees, providing a favorable environment. ${ }^{26}$

It is worth noting that in the Situational Leadership model, strategies must be developed to minimize gaps, such as communication aspects, and feedback between leader and subordinates must be maximized. The situational leader must have knowledge and skills to nurture the subordinate professional development while helping him to develop his knowledge of himself and the context in which he carry out his practice. The supportive environment for professional practice mediates the relationship between authentic leadership and job satisfaction.

Synthesizing the findings, it is highlighted that the relationship between leadership and the impacts on work processes and organizational climate, which includes job satisfaction, will occur according to the level of empowerment, supervised support and aid to the leader's professional practice with the subordinates and vice versa.

Regarding nursing empowerment, it should be noted that the leader's leadership style will depend effectively on the effective development of leadership, as well as on strategies to promote the leader's autonomy and to encourage the empowerment of the team and to understand and meet the real needs, seeking harmony in the work environment, working on group union and integration, ensuring subordinates satisfaction and work processes that favors patient safety. ${ }^{26-29}$

\section{Conclusion}

It is evident there is a generalized awareness of the need for an active leadership within nursing environment. In this aspect, leadership profiles vary, and can be more horizontal, flexible, and dynamic (as revealed in moderate and strategic leadership), as well as lead to a more vertical profile (based on hierarchy and division of work activities, as seen in authoritarian and persuasive leadership). Positive and supportive leadership styles can improve organizational commitment, help maintaining a favorable climate for the worker's well-being, which will bring higher levels of job satisfaction for nurses, and at the same time can reduce emotional exhaustion.

The authentic leadership style was also pointed as positive in maintaining the organizational climate and job satisfaction since it 
leads to empowerment and autonomy of the team in sharing decisions and managing care process itself.

Understanding optimal leadership styles can assist in the process of recruiting and training staff with leadership roles at positioned jobs. Positive leadership will provide more aligned work processes, as well as a wellness organizational climate which results in positive outcomes for professionals and patients. When understood the different effects of leadership styles and how they can impact the work environment, team bonding, as well as when a particular leadership style benefits or detracts from organizational goals, one can design more targeted leadership development programs. It is necessary to develop leadership skills in order to positively affect the nursing work processes in favor of achieving high indicators of health quality management, as well as the persuit for job satisfaction.

This review was based on a limited number of eligible studies, most of which were cross-sectional studies susceptible to biases due to study design. There is a possibility of publication bias since not all included studies performed correlation analysis, as well as studies with negative results may not have been published, and/ or correlations between leadership style, organizational climate and job satisfaction may have been overestimated. Another limiting factor is the non-inclusion of theses and essays, and inclusion of only English and Portuguese language articles and so more relevant studies could have been found in other languages. A thorough quality assessment process, based on independent review by two authors and the use of previously validated quality assessment tools, helped to ensure that the results received appropriate consideration and weight, and helped the authors to determine where high-quality research may be lacking.

\section{Acknowledgement}

The authors would like to thank the University of São Paulo's unified scholarship program for supporting the permanence and training of undergraduate students (PUB-USP), which is part of the Policy for Supporting the Permanence and Training of Students, which granted two scientific initiation scholarships to nursing students.

\section{Funding}

None.

\section{Conflicts of Interest}

The authors have no disclosures or conflicts of interest.

\section{References}

1. Scofano BS, Valente GSC, Lanzillotti RS. Nurses' role as team leader in the hospital area: an integrative review. Atuação do enfermeiro enquanto líder de equipe na área hospitalar: uma revisão integrativa (portuguese). Nursing (São Paulo). 2019;22(253):2943-2948.
2. Andrique KCK, Trindade LL, Amestoy SC, et al. Estilos de liderança situacional adotados pelos enfermeiros na área hospitalar. Rev Eletrôn Enferm. 2016;18.

3. Silva VLS, Camelo SHH, Soares MI, et al. Leadership practices in hospital nursing: a self of manager nurses. Rev Esc Enferm. 2017;51:e03206.

4. Pathania A, Rasool G. Investigating power styles and behavioral compliance for effective hospital administration. Int J Health Care Qual Assur. 2019;32(6):958-977.

5. Jeroen WB, Peters PFR. Leadership in Maintaining Standards for the APN Role, Advanced Practice Nursing Leadership: A Global Perspective. 2020; pp. 167-183.

6. Joanna Briggs Institute (JBI). Joanna Briggs Reviewers' Manual: 2014 edition 2014a.

7. Abdelhafiz IM, Alloubani AM, Almatari M. Impact of leadership styles adopted by head nurses on job satisfaction: a comparative study between governmental and private hospitals in Jordan. J Nurs Manag. 2016;24(3):384-392.

8. Choi SL, Goh CF, Adam MB, et al. Transformational leadership, empowerment, and job satisfaction: the mediating role of employee empowerment. Hum Res Health. 2016;14(1):73.

9. Naseem S, Afzal M, Sehar S, et al. Relationship between Leadership Styles of Nurse Managers and Staff Nurses Job Satisfaction in Public Hospital of Punjab, Pakistan. Int J Soc Sci Manag. 2018;5:201-208.

10. Pishgooie AH, Atashzadeh Shoorideh F, Falcó Pegueroles A, et al. Correlation between nursing managers' leadership styles and nurses' job stress and anticipated turnover. J Nurs Manag. 2019;27(3):527-534.

11. Suliman M, Aljezawi M, Almansi S, et al. Effect of nurse managers' leadership styles on predicted nurse turnover. Nurs Manag (Harrow). 2020;27(5):20-25.

12. Sabbah IM, Ibrahim TT, Khamis RH, et al. The association of leadership styles and nurses well-being: a cross-sectional study in healthcare settings. Pan Afr Med J. 2020;36:328.

13. Alloubani A, Akhu Zaheya L, Abdelhafiz IM, et al. Leadership styles' influence on the quality of nursing care. Int J Health Care Qual Assur. 2019;32(6):1022-1033.

14. Specchia ML, Cozzolino MR, Carini E, et al. Leadership Styles and Nurses' Job Satisfaction. Results of a Systematic Review. Int J Environ Res Public Health. 2021;18(4):1552.

15. Brewer CS, Kovner CT, Djukic M, et al. Impact of transformational leadership on nurse work outcomes. J Adv Nurs. 2016;72(11):2879-2893.

16. Asiri SA, Rohrer WW, Al Surimi K, et al. The association of leadership styles and empowerment with nurses' organizational commitment in an acute health care setting: A cross-sectional study. $B M C$ Nursing. 2016;9:15-38.

17. García Sierra R, Fernández Castro J. Relationships between leadership, structural empowerment, and engagement in nurses. J Adv Nurs. 2018;74(12):2809.

18. Musinguzi C, Namale L, Rutebemberwa E, et al. The relationship between leadership style and health worker motivation, job satisfaction and teamwork in Uganda. J Healthc Leadersh. 201;10:21-32.

19. Saleh U, O'Connor T, Al Subhi H, et al. The impact of nurse managers' leadership styles on ward staff. Br J Nurs. 2018;27(4):197-203.

20. Moura AA, Hayashida KY, Bernardes A, et al. Charismatic leadership among nursing professionals: an integrative review. Rev Bras Enferm. 2019;72(1):315-320.

21. Malik N, Dhar RL, Handa SC. Authentic leadership and its impact on creativity of nursing staff: A cross sectional questionnaire survey of Indian nurses and their supervisors. Int J Nurs Stud. 2016;63:28-36. 
22. Fallatah F, Laschinger HK. The influence of authentic leadership and supportive professional practice environments on new graduate nurses job satisfaction. J Res Nurs. 2016;21(2):125-136.

23. Jackson C. Review: The influence of authentic leadership and supportive professional practice environments on new graduate nurses job satisfaction. J Res Nurs. 2016;21(2):137-138.

24. Özkan Tuncay F, Yașar Ö, Sevimligül G. Conflict management styles of nurse managers working in inpatient institutions: the case of Turkey. J Nurs Manag. 2018;26(8):945-952.

25. Magbity JB, Ofei AMA, Wilson D. Leadership Styles of Nurse Managers and Turnover Intention. Hosp Top. 2020;98(2):45-50.
26. Moura, André Almeida de, Bernardes A, Pazetto Balsanelli A, et al. Liderança e satisfação no trabalho da enfermagem: revisão integrativa. Acta Paulista de Enfermagem [online]. 2017;30(4):442-450.

27. Kaiser JA. The relationship between leadership style and nurse-tonurse incivility: Turning the lens inward. Journal of Nursing Management. 2017;25:110-118.

28. Poels J, Verschueren M, Milisen K, et al. Leadership styles and leadership outcomes in nursing homes: a cross-sectional analysis. $B M C$ Health Serv Res. 2020;20(1):1009.

29. Yeh SJ, Yuan KS, Chen SS, et al. The moderating effect of leadership on the relationship between personality and performance. J Nurs Manag. 2016;24(7):869-883. 